\title{
Anemia pada ibu hamil peserta Program 1000 Hari Pertama Kehidupan di Agats, Asmat, Papua: Prevalensi dan analisis faktor risiko
}

\author{
Pritania Astari, ${ }^{1,{ }^{*}}$ Hanggoro Tri Rinonce, ${ }^{2}$ Maria Fransiska Pudjohartono, ${ }^{1}$ Josephine Debora, ${ }^{1}$ \\ Monica Gisela Winata, ${ }^{1}$ Fadli Kasim ${ }^{3}$ \\ ${ }^{1}$ Mahasiswa Program Studi Profesi Dokter, Fakultas Kedokteran, Kesehatan Masyarakat, dan \\ Keperawatan, Universitas Gadjah Mada, Yogyakarta, Indonesia \\ ${ }^{2}$ Departemen Patologi Anatomik, Fakultas Kedokteran, Kesehatan Masyarakat, dan Keperawatan, \\ Universitas Gadjah Mada, Yogyakarta, Indonesia \\ ${ }^{3}$ Departemen Teknik Nuklir dan Teknik Fisika, Fakultas Teknik, Universitas Gadjah Mada, Yogyakarta, \\ Indonesia
}

Submitted: 30 September 2018 Revised: 23 Oktober 2018 Accepted: 7 November 2018

\begin{abstract}
ABSTRAK Pada tahun 2013, terdapat 37,0\% kasus anemia pada ibu hamil di Indonesia. Kejadiannya di Agats, Asmat, Papua masih merupakan fenomena gunung es yang belum banyak mendapat sorotan. Pusat Kesehatan Masyarakat (Puskesmas) Agats menjalankan Program 1000 Hari Pertama Kehidupan (HPK) sejak tahun 2016 untuk meningkatkan kualitas kehamilan dan kelahiran. Penelitian ini bertujuan untuk mengetahui prevalensi anemia pada ibu hamil peserta Program 1000 HPK serta menganalisis faktor-faktor yang berpengaruh terhadap anemia pada ibu hamil di Agats, Asmat, Papua. Penelitian ini merupakan penelitian deskriptif observasional, menggunakan data sekunder dari laporan evaluasi Program 1000 HPK Puskesmas Agats Oktober 2017, yang diambil pada periode pelaksanaan Kuliah Kerja Nyata - Peduli Bencana (KKN-PB) Universitas Gadjah Mada (UGM), 17 Maret sampai 30 April 2018. Sebanyak 97 ibu hamil dari 230 peserta Program 1000 HPK dilibatkan dalam penelitian ini. Data yang diambil meliputi umur kehamilan, kadar hemoglobin ( $\mathrm{Hb}$ ), lingkar lengan atas (LLA), berat badan, dan pemberian suplemen zat besi. Kadar $\mathrm{Hb}<11 \mathrm{~g} / \mathrm{dL}$ pada trimester I atau $<10,5 \mathrm{~g} / \mathrm{dL}$ pada trimester II dan III digolongkan sebagai anemia. Dilakukan pula analisis kemungkinan faktor risiko anemia berdasarkan hasil observasi di Agats dengan tinjauan pustaka. Dari total 97 ibu hamil peserta Program 1000 HPK, sebanyak 45,4\% orang menderita anemia, meskipun $43,4 \%$ di antaranya telah mendapatkan suplementasi zat besi. Sebanyak $24,7 \%$ ibu hamil memiliki LLA $<23 \mathrm{~cm}$. Beberapa kemungkinan faktor risiko anemia pada ibu hamil di Agats meliputi letak geografis Asmat, rendahnya tingkat pendidikan masyarakat, minimnya tenaga kesehatan serta fasilitas pelayanan kesehatan, kurangnya perhatian masyarakat terhadap kesehatan, keadaan sosioekonomi rendah, dan status gizi ibu hamil. Prevalensi anemia pada ibu hamil peserta Program 1000 HPK di Agats, Asmat, Papua pada Oktober 2017 lebih tinggi daripada prevalensi nasional. Penelitian lebih lanjut dibutuhkan untuk mengetahui kaitan pasti antara kejadian anemia pada ibu hamil di Agats dengan faktor-faktor risiko tersebut.
\end{abstract}

KATA KUNCI anemia; kehamilan; 1000 hari pertama kehidupan; Asmat; Papua

ABSTRACT In 2013, it was found that 37\% pregnant women in Indonesia suffered from anemia. However, in Agats, Asmat, Papua, this phenomenon has not gained enough attention. In order to improve the quality of birth and pregnancy, Pusat Kesehatan Masyarakat (Puskesmas) Agats is currently implementing the

\footnotetext{
*Corresponding author: Pritania Astari

Fakultas Kedokteran, Kesehatan Masyarakat, dan Keperawatan, Universitas Gadjah Mada, J. Farmako, Sekip Utara, Yogyakarta 55281, Indonesia

E-mail: pritania.astari@mail.ugm.ac.id
} 
First 1000 Days of Life (1000 HPK) Program since 2016. This study aimed to discover the prevalence of anemia in pregnancy of the 1000 HPK participants in Agats and to understand the possible contributing risk factors. This study was descriptive observational study using secondary data from the evaluation report of 1000 HPK Program in Puskesmas Agats during October 2017. From 230 participants of 1000 HPK Program, 97 of them who were pregnant, were taken as the sample. The data (gestational age, hemoglobin level, upper arm circumference, body weight, and history of iron supplementation) were obtained during the implementation of Kuliah Kerja Nyata - Peduli Bencana (KKN-PB) Universitas Gadjah Mada (UGM), from March $17^{\text {th }}$ to April $30^{\text {th }}, 2018$. Hemoglobin level in the first trimester $<11 \mathrm{~g} / \mathrm{dL}$ or in the second and third trimester $<10.5 \mathrm{~g} / \mathrm{dL}$ were classified as anemia. The observed risk factors were then analyzed using literature review. From 97 participants of 1000 HPK Program, 45.4\% suffered from anemia, even though $43.4 \%$ of them had received iron supplementation. Moreover, $24.7 \%$ of the pregnant women had midupper arm circumference $<23 \mathrm{~cm}$. Several observed influencing risk factors included the geographic profile of Asmat, low educational status, lacking of health personnels, facilities and the general awareness of the citizens regarding maternal health, low socio-economical status, and low maternal nutritional status. The prevalence of anemia in the pregnant participants of 1000 HPK Program in Agats, Asmat, Papua, during October 2017 was higher than the national prevalence. Further study needs to be conducted in order to find the correlation between the prevalence of anemia in the pregnant participants of 1000 HPK Program in Agats and the suspected risk factors.

KEYWORDS anemia; pregnancy; first 1000 days of life; Asmat; Papua

\section{Pendahuluan}

Asmat merupakan sebuah kabupaten di Papua, Indonesia, yang akhir-akhir ini mendapatkan banyak perhatian dari masyarakat. Salah satu penyebabnya adalah status kejadian luar biasa (KLB) campak dan gizi buruk yang ditetapkan oleh pemerintah pada bulan Januari 2018. ${ }^{1}$ Kondisi demografis yang kurang menguntungkan, tingkat pendidikan yang rendah, kebudayaan setempat, serta minimnya fasilitas kesehatan dan tenaga kesehatan seringkali membuat warga Asmat tidak memperhatikan kesehatan mereka. ${ }^{2}$ Dalam menghadapi kehamilan, masyarakat Asmat juga belum menaruh perhatian lebih. Tidak sedikit warga Asmat yang berpendapat bahwa proses kehamilan merupakan hal alami sehingga tidak membutuhkan perhatian khusus, padahal pada kehamilan terdapat beberapa perubahan fisiologis maternal yang perlu diperhatikan untuk mendukung keberlangsungan hidup janin. ${ }^{3}$

Pemantauan kondisi ibu selama kehamilan sangat penting untuk memastikan kesehatan ibu dan janin. Pada kehamilan, sering didapatkan penurunan kadar hemoglobin akibat peningkatan volume darah pada ibu. ${ }^{4}$ Apabila tidak mendapatkan intervensi, kondisi tersebut dapat berkembang menjadi anemia pada kehamilan yang dapat berakibat fatal. Faktor-faktor lain seperti asupan nutrisi yang buruk, infestasi parasit seperti malaria, serta infeksi mikroorganisme, dapat memperburuk luaran klinis hingga menimbulkan komplikasi seperti kematian. ${ }^{5}$

Pada tahun 2011, di dunia, 38,2\% ibu hamil mengalami anemia, dengan prevalensi tertinggi di Afrika (44,6\%), diikuti oleh Asia dengan prevalensi sebesar $39,3 \% .^{6}$ Sedangkan, di Indonesia pada tahun 2013, prevalensi anemia pada ibu hamil mencapai 37,0\%. ${ }^{7}$ Beberapa studi menyebutkan bahwa anemia pada kehamilan berkontribusi secara tidak langsung pada 23,0\% kasus kematian ibu di negara berkembang. ${ }^{8}$ Perdarahan saat kelahiran yang pada umumnya tidak berbahaya bagi ibu dengan kadar hemoglobin normal, dapat menimbulkan komplikasi yang berat pada ibu dengan anemia. ${ }^{9}$ Selain itu, anemia pada ibu hamil juga kerap dikaitkan dengan komplikasi neonatal seperti peningkatan risiko bayi lahir prematur, berat badan lahir rendah, kematian janin, serta 
janin tumbuh lambat. ${ }^{5,8}$

Oleh karena itu, sejak tahun 2016, Puskesmas Agats, Asmat, mengadakan Program 1000 Hari Pertama Kehidupan (HPK) untuk mengurangi angka kematian ibu dan anak, serta menjamin kesehatan ibu dan anak selama masa kehamilan hingga dua tahun setelah anak lahir. Program ini mencakup pemberian makan dan suplementasi untuk ibu hamil, pemeriksaan antropometri, penyuluhan terkait perilaku hidup bersih sehat (PHBS), air susu ibu (ASI) eksklusif, dan penyuluhan secara pribadi; serta pemeriksaan ibu hamil secara berkala oleh petugas kesehatan (antenatal care/ ANC). ${ }^{10}$

Asmat belum lepas dari permasalahan gizi dan angka kematian ibu yang tinggi, serta merupakan daerah endemik malaria, sehingga kemungkinan besar banyak ibu hamil dengan anemia. Hingga saat ini, belum ada penelitian terkait prevalensi serta analisis faktor risiko anemia pada ibu hamil di Agats, Asmat, Papua. Penelitian ini bertujuan untuk mengetahui prevalensi dan faktor risiko anemia pada ibu hamil peserta Program 1000 HPK di Agats, Asmat. Data tersebut dapat dijadikan sebagai dasar kebijakan yang lebih baik untuk penanganan anemia pada ibu hamil, sehingga angka kematian ibu karena anemia pada kehamilan dapat diturunkan di masa yang akan datang.

\section{Metode}

Penelitian ini merupakan penelitian deskriptif observasional. Data sekunder diambil dari laporan evaluasi Program 1000 HPK di Puskesmas Agats pada Oktober sampai Desember 2017. Data tersebut mencakup jumlah peserta Program 1000 HPK, jumlah ibu hamil pada program tersebut, kadar hemoglobin peserta Program 1000 HPK, status antropometri peserta berupa lingkar lengan atas (LLA) dan berat badan, serta pemberian suplementasi zat besi pada peserta program.

Pengambilan data dilakukan dalam rangka pelaksanaan program kerja Kuliah Kerja Nyata Peduli Bencana (KKN-PB) UGM dengan tema Promosi Kesehatan serta Pemberdayaan Masyarakat di Bidang Pendidikan, Ekonomi, dan Lingkungan pada periode 17 Maret - 30 April 2018. Data yang diperoleh berasal dari laporan evaluasi Program 1000 HPK pada Oktober 2017. Kegiatan tersebut dilaksanakan di delapan posko yang tersebar di distrik Agats, Asmat, Papua, yaitu Posko Syuru, Posko Bintang Laut, Posko Pemda, Posko Dolog (GOR), Posko Yayasan Kemajuan dan Pengembangan Asmat (YKPA), Posko Cemenes, Posko Pelabuhan Lama, dan Posko Mbait II. Sebagian data diambil dengan cara mendatangi langsung warga dari rumah ke rumah.

Anemia pada ibu hamil didefinisikan sebagai kadar hemoglobin darah $<11 \mathrm{~g} / \mathrm{dL}$ pada trimester I atau $<10,5 \mathrm{~g} / \mathrm{dL}$ pada trimester II - III sesuai definisi dari Royal College of Obstetricians and Gynaecologists (RCOG). ${ }^{11}$ Pada Program 1000 HPK di Agats, Asmat, terdapat 230 orang peserta yang mencakup ibu hamil dan ibu tidak hamil yang memiliki anak berusia sampai dengan dua tahun. Penelitian ini mengambil sampel seluruh ibu hamil peserta Program 1000 HPK yang berjumlah 97 orang. Karena keterbatasan pengambilan data, hanya ibu-ibu hamil yang mempunyai data usia kehamilan yang dianalisis pada penelitian ini. Sedangkan, untuk analisis faktor risiko, digunakan metode telaah pustaka dari studi-studi terkait, kemudian dihubungkan dengan hasil observasi yang didapatkan di Asmat sebagai prediktor kemungkinan faktor risiko anemia pada ibu hamil di Asmat.

\section{Hasil}

Pada bulan Oktober 2017, terdapat 230 peserta Program 1000 HPK. Di antara peserta tersebut, terdapat 97 (42,2\%) ibu hamil. Pengukuran LLA pada penelitian ini dilakukan untuk menilai status gizi. Tabel 1 menunjukkan karakteristik ibu hamil peserta Program 1000 HPK pada Oktober 2017. Sebanyak $24(24,7 \%)$ ibu hamil memiliki LLA $<23$ $\mathrm{cm}$. Rata-rata LLA seluruh peserta adalah $24,4 \mathrm{~cm}$ (terpendek $19 \mathrm{~cm}$, terpanjang $36 \mathrm{~cm}$ ). Berat badan rata-rata seluruh peserta adalah $55,7 \mathrm{~kg}$ (teringan $40 \mathrm{~kg}$, terberat $83 \mathrm{~kg})$. Empat puluh empat (45,5\%) ibu hamil mengalami anemia, meskipun selama kehamilan $89(91,8 \%)$ ibu hamil telah mendapatkan suplemen zat besi. Tabel 2 menunjukkan bahwa anemia paling banyak terjadi pada trimester kedua 
Tabel 1. Karakteristik ibu hamil peserta Program 1000 HPK di Puskesmas Agats pada Oktober 2017

\begin{tabular}{lc}
\hline Karakteristik & \\
\hline LLA $(\mathrm{cm}), \mathrm{n}(\%)$ & $24(24,7)$ \\
$<23 \mathrm{~cm}$ & $73(75,3)$ \\
$\geq 23 \mathrm{~cm}$ & \\
Berat badan $(\mathrm{kg})$ & 24.4 \\
$\quad$ Rata-rata & 19 \\
$\quad$ Teringan & 83 \\
$\quad$ Terberat & \\
Pemberian suplemen zat besi & \\
selama kehamilan, $\mathrm{n}(\%)$ & $89(91,8)$ \\
$\quad$ Ya & $8(8,2)$ \\
$\quad$ Tidak & \\
Anemia, $\mathrm{n}(\%)$ & $44(45,4)$ \\
$\quad$ Ya & $53(54,6)$ \\
$\quad$ Tidak & \\
Jumlah total ibu hamil= 97, LLA: lingkar lengan atas.
\end{tabular}

Tabel 2. Prevalensi anemia pada tiap trimester kehamilan

\begin{tabular}{lcc}
\hline & $\mathbf{n}$ & $\%$ \\
\hline Trimester I & 16 & 16,4 \\
Trimester II & 21 & 21,6 \\
Trimester III & 7 & 7,2 \\
Total & 44 & 45,2 \\
\hline
\end{tabular}

Jumlah total ibu hamil= 97.

Tabel 3. Distribusi suplementasi zat besi pada ibu hamil dengan anemia

\begin{tabular}{lcc}
\hline & $\begin{array}{c}\text { Mendapat } \\
\text { suplemen } \\
\text { zat besi }\end{array}$ & $\begin{array}{c}\text { Tidak } \\
\text { mendapat } \\
\text { suplemen } \\
\text { zat besi }\end{array}$ \\
\hline Anemia, $\mathrm{n}(\%)$ & $42(43,3)$ & $2(2,1)$ \\
Tidak anemia, $\mathrm{n}(\%)$ & $47(48,4)$ & $6(6,2)$ \\
\hline
\end{tabular}

Jumlah total ibu hamil= 97 .

(21,6\%). Sebanyak $42(43,3 \%)$ ibu hamil penderita anemia telah mendapatkan suplementasi zat besi (Tabel 3).

\section{Pembahasan}

Hasil penelitian ini menunjukkan bahwa prevalensi anemia pada ibu hamil peserta Program 1000 HPK di distrik Agats pada bulan Oktober 2017 mencapai 45,4\%. Angka ini lebih tinggi dibandingkan prevalensi anemia pada ibu hamil di Indonesia, yaitu sebesar $37,1 \%$. $^{7}$ Beberapa faktor yang dapat berkontribusi pada kejadian tersebut antara lain meliputi letak geografis Asmat, rendahnya tingkat pendidikan masyarakat, minimnya tenaga kesehatan serta fasilitas pelayanan kesehatan, kurangnya perhatian masyarakat terhadap kesehatan, keadaan sosioekonomi rendah, serta status gizi ibu hamil di Asmat.

Dari segi geografis, kabupaten Asmat yang terletak di bagian selatan Papua memang sulit dijangkau. ${ }^{12}$ Untuk mencapai distrik Agats selaku ibukota Kabupaten Asmat, perlu dilakukan perjalanan udara dan atau air yang hanya dapat diakses dari Timika atau Merauke. ${ }^{13} \mathrm{Hal}$ ini sangat berdampak pada sukarnya distribusi barang, baik untuk kebutuhan sehari-hari maupun keperluan rumah sakit, yang seringkali harus dikirimkan dari kota lain. Selain itu, tekstur tanah serta curah hujan di Agats juga tidak mendukung kegiatan bercocok tanam sehingga ketersediaan sebagian besar bahan makanan juga bergantung pada proses distribusi tersebut. ${ }^{12}$

Pada kehamilan, nutrisi merupakan salah satu hal yang paling penting untuk diperhatikan. ${ }^{14}$ Diet ibu yang seimbang turut berperan serta dalam menjaga kesehatan ibu dan anak selama masa kehamilan. Asupan nutrisi yang baik juga sangat membantu dalam mencegah kejadian anemia pada kehamilan. Ibu hamil dianjurkan untuk mengonsumsi setidaknya $27 \mathrm{mg}$ zat besi per hari. Pilihan makanan yang dianjurkan untuk mencegah anemia antara lain daging merah, ayam, ikan, serta kacang-kacangan. ${ }^{14} \mathrm{Di}$ antara jenis makanan tersebut, ikan adalah yang paling mungkin didapatkan di Agats. ${ }^{15}$ 
Pada Program 1000 HPK, ibu-ibu hamil di Agats mendapatkan makanan setiap hari Senin sampai Jumat yang didistribusikan di beberapa pondok bersalin desa (polindes). Menu yang diberikan bervariasi, dan sudah mencakup lauk berupa ayam, ikan, atau telur. Namun, asupan gizi ibu hamil di luar pemberian makan tersebut memang sulit untuk dikontrol, terutama karena kesadaran tiap individu maupun komunitas tentang kesehatan masih sangat rendah. Bahkan, terkadang peserta malas untuk datang ke polindes. Selain itu, berdasarkan laporan evaluasi Program 1000 HPK Puskesmas Agats, petugas kesehatan setempat juga mengungkapkan bahwa seringkali peserta menolak makan di posko dan makanan yang didistribusikan dibawa pulang untuk kemudian dimakan oleh anak atau suami mereka. ${ }^{16} \mathrm{Hal}$ ini dapat terjadi karena rendahnya tingkat pendidikan di Asmat yang membuat masyarakat kurang memperhatikan kesehatan maupun status gizi mereka. Pada tahun 2017 sebanyak $50,4 \%$ penduduk Asmat tidak memiliki ijazah dengan hanya $5,6 \%$ penduduk yang memiliki ijazah sekolah menengah atas atau sederajat dan $1,1 \%$ penduduk yang memiliki diploma. Jumlah sekolah di Agats juga masih tergolong sedikit, yaitu sebanyak 11 sekolah dasar, 6 sekolah menengah pertama, dan 3 sekolah menengah atas dengan angka partisipasi sekolah usia 7-12 tahun sebanyak $81,8 \%, 13-15$ tahun sebanyak $77,7 \%$, dan $16-18$ tahun sebanyak $58,6 \%$.

Kondisi sosioekonomi di Asmat yang cukup memprihatinkan juga membuat masyarakat secara umum masih kesulitan dalam memenuhi kebutuhan makanan sehari-hari. Sebanyak $45,7 \%$ penduduk Asmat bekerja di sektor agrikultur dengan pendapatan sehari-hari yang tidak pasti. Pada tahun 2017, terdapat 27,0\% penduduk Asmat yang berada di bawah garis kemiskinan. ${ }^{15}$ Beberapa penelitian lain di negara berkembang seperti Etiopia dan Tanzania mengungkapkan bahwa status sosioekonomi serta pendidikan cukup berpengaruh pada kejadian anemia pada ibu hamil. Ibu hamil yang memiliki pendidikan tinggi atau keadaan sosioekonomi yang baik, lebih jarang terkena anemia karena mereka cenderung akan memakan makanan yang bergizi tinggi. Selain itu, mereka juga lebih sadar akan hal-hal yang diperlukan untuk menjaga kesehatan ibu dan anak selama kehamilan. ${ }^{17,18}$

Kebudayaan Asmat juga terbilang cukup unik dalam memandang peran perempuan dalam keluarga. Masyarakat Asmat menempatkan perempuan sebagai tulang punggung keluarga yang wajib mencari makan dan memenuhi kebutuhan sehari-hari keluarganya. ${ }^{19} \mathrm{Hal}$ tersebut mau tidak mau berpengaruh pada efektivitas pembagian makanan di polindes karena pada akhirnya membuat ibu-ibu hamil di Asmat menganggap makanan yang mereka dapatkan sebagai makanan yang bisa diberikan untuk keluarga. ${ }^{16}$ Selain itu, budaya Asmat sangat mendukung terjadinya proses kehamilan dan kelahiran sebanyak-banyaknya. Sehingga, dalam satu keluarga bisa terdapat setidaknya lima orang anak dari seorang ibu yang sama. ${ }^{19}$ Beberapa penelitian yang dilakukan di negara berkembang menyatakan bahwa tidak ada keterkaitan antara multigravida dengan anemia., ${ }^{5,17}$ Kendati demikian, sebuah penelitian di Turki menemukan hubungan bermakna antara jumlah paritas dengan kejadian anemia pada ibu hamil. ${ }^{9}$ Beberapa penelitian juga meninjau korelasi antara jumlah anggota keluarga dengan kecenderungan seorang ibu hamil mengalami anemia. Sebuah studi di Etiopia menemukan bahwa ibu hamil yang tinggal dengan lebih dari empat orang anggota keluarga, memiliki kemungkinan yang lebih besar untuk menderita anemia. ${ }^{17}$ Sebaliknya, penelitian di Jordan tidak menemukan perbedaan bermakna antara jumlah anggota keluarga dengan anemia pada ibu hamil. ${ }^{20}$ Oleh karena itu, status gravida, paritas, abortus, serta jumlah anggota keluarga merupakan variabel yang penting untuk diperhitungkan dalam penelitian selanjutnya, terutama apabila menghendaki suatu studi korelasi.

Selain kesadaran masyarakat yang rendah, fasilitas kesehatan serta tenaga kesehatan di Asmat juga masih tergolong kurang. Pada tahun 2017 hanya terdapat satu Puskesmas di Agats dan satu RSUD di seluruh Asmat. Puskesmas tersebut tidak memiliki dokter, dan, secara keseluruhan, Asmat 
hanya memiliki tujuh dokter spesialis serta 24 dokter umum per 92.909 penduduk. Sementara itu, jumlah perawat dan bidan berturut-turut adalah 217 dan 106 orang per 92.909 penduduk. ${ }^{15}$ Angka ini masih jauh dari sasaran Kepmenkes No. 81 Tahun 2004 yang menargetkan pada tahun 2019 setidaknya terdapat 24 dokter spesialis dan 96 dokter umum per 100.000 penduduk. Sedangkan, untuk jumlah perawat dan bidan telah mencapai target yaitu 158 perawat dan 75 bidan per 100.000 penduduk. ${ }^{21} \mathrm{Hal}$ ini tentu memengaruhi kualitas pelayanan kesehatan di Asmat secara keseluruhan sehingga standar pelayanan kesehatan terhadap ibu hamil sulit tercapai.

Sekali pun menurut data yang diambil dari Kabupaten Asmat dalam Angka, presentase ibu hamil pada tahun 2016 yang melakukan kunjungan ANC pada trimester pertama sudah mencapai $190 \%$, data ini termasuk sulit untuk dipercaya kesahihannya karena tercatat jumlah ibu yang melakukan ANC jauh melebihi jumlah ibu hamil pada saat itu. Padahal, kunjungan ANC pada trimester pertama dan jumlah total kunjungan ANC selama kehamilan dinilai sebagai faktor protektif yang bermakna dalam beberapa penelitian. ${ }^{5,17}$ WHO merekomendasikan ibu hamil untuk melakukan setidaknya delapan kali kunjungan ANC yang diawali pada minggu ke- 12 kehamilan. ${ }^{22}$ ANC merupakan agenda yang rutin dilakukan pada Program 1000 HPK Puskesmas Agats. Namun, kepatuhan peserta serta kelengkapan pengukuran yang dilakukan belum terevaluasi dengan baik. Hal tersebut penting untuk diperbaiki pada penelitianpenelitian selanjutnya agar hubungan antara kunjungan ANC dan kejadian anemia pada ibu hamil di Agats dapat dikaji lebih dalam.

Rata-rata status gizi ibu hamil peserta Program 1000 HPK di Agats, Asmat sudah baik. Penilaian status gizi tersebut dilakukan dengan menggunakan kriteria LLA, karena data tinggi badan untuk pengukuran body mass index (BMI) tidak tersedia. Kendati demikian, masih terdapat $24,7 \%$ ibu hamil dengan LLA $<23 \mathrm{~cm}$. Pengukuran lingkar lengan atas dalam menilai status gizi merupakan parameter yang bermakna. Sebuah penelitian menyatakan bahwa LLA yang rendah berkaitan dengan BMI $<18,5 \mathrm{~kg} / \mathrm{m}^{2}{ }^{23}$ Saat ini belum ada kesepakatan mengenai nilai ambang batas LLA yang digunakan sebagai prediktor gizi kurang, namun sebuah studi literatur menyatakan bahwa LLA $<23 \mathrm{~cm}$ pada ibu hamil di Indonesia dapat menjadi nilai batas terbawah untuk memprediksi malnutrisi karena keterkaitannya dengan komplikasi postnatal seperti berat badan lahir rendah atau janin tumbuh lambat. ${ }^{24}$ Pada tahun 2016, terdapat 6,7\% ibu hamil di seluruh Asmat yang menderita keadaan kurang energi kronis (KEK), namun keterkaitannya dengan anemia pada ibu hamil di daerah ini belum ditemukan, sehingga perlu diteliti lebih lanjut. Sebuah penelitian di Medan mengungkapkan bahwa keadaan KEK pada ibu hamil dapat berkaitan dan dapat menjadi faktor risiko anemia pada kehamilan. ${ }^{25}$

Asmat juga merupakan daerah endemis malaria yang dapat berkontribusi pada kejadian anemia. ${ }^{26}$ Angka kejadian malaria di Asmat pada tahun 2016 mencapai 66,1\% kasus dari seluruh populasi, ${ }^{27}$ sedangkan di Agats pada tahun 2017, tercatat 331 kejadian malaria per 15.103 penduduk $(2,2 \%) .{ }^{15}$ Malaria dapat menyerang siapa saja tanpa terkecuali, termasuk ibu hamil. Sayangnya upaya masyarakat untuk mencegah malaria seperti menjaga sanitasi lingkungan, atau penggunaan penangkal nyamuk seperti kelambu, masih belum banyak diterapkan. Di Tanzania, pemberian profilaksis malaria dan obat cacing untuk ibu hamil yang harus diminum di depan petugas kesehatan sudah dipraktekkan. ${ }^{5} \mathrm{Hal}$ ini belum tercakup pada Program 1000 HPK yang diadakan oleh Puskesmas Agats.

Anemia pada kehamilan kerap dikaitkan dengan berbagai komplikasi, di antaranya adalah berat badan lahir rendah. ${ }^{28}$ Pada tahun 2013, di Asmat, terdapat 7,5\% bayi yang lahir dengan berat badan lahir rendah (<2500 gram) ${ }^{15}$ Angka ini lebih rendah dibandingkan presentase berat badan lahir rendah nasional $(10,2 \%)$ maupun di Provinsi Papua $(15,2 \%){ }^{7}$ Pada tahun 2016, prevalensi berat badan lahir rendah di Asmat kembali turun menjadi $2,9 \% .{ }^{15}$ Pada penelitian ini, angka tersebut 
belum dapat dikaitkan secara langsung dengan kejadian anemia pada ibu hamil di Asmat. Oleh karena itu, diperlukan penelitian lebih lanjut untuk mengetahui hal tersebut. Sebuah studi tinjauan sistematis menemukan bahwa anemia pada ibu hamil, terutama pada trimester pertama, merupakan faktor risiko berat badan lahir rendah. ${ }^{28}$ Studi lain di Karnataka, India juga menemukan hubungan yang bermakna antara anemia pada ibu hamil dengan kejadian berat badan lahir rendah. ${ }^{29}$

Pada penelitian ini, kejadian anemia pada ibu hamil paling banyak dijumpai pada trimester kedua $(21,6 \%)$. Penelitian lain yang dilakukan di India menunjukkan hasil yang sama, sebanyak $64,7 \%$ ibu hamil di trimester kedua mengalami anemia. ${ }^{29} \mathrm{Hal}$ ini dapat dicegah dengan pemberian suplementasi zat besi sejak trimester pertama, terutama apabila diketahui kadar hemoglobin ibu hamil $\leq 11,0 \mathrm{~g} / \mathrm{dL} .^{22}$ Secara keseluruhan, distribusi suplementasi zat besi pada Program 1000 HPK di Agats telah mencapai 91,8\% dan pemberian suplementasi zat besi untuk ibu yang menderita anemia mencapai $43.3 \%$. Angka ini lebih tinggi dibandingkan cakupan pemberian suplementasi zat besi untuk ibu hamil di seluruh Asmat pada tahun 2016 (52,0\%), ${ }^{15}$ maupun Papua pada tahun 2015 (33,0\%). ${ }^{27}$ WHO menyarankan konsumsi 30-60 mg suplemen zat besi setiap hari untuk ibu hamil, sedangkan Kementrian Kesehatan Republik Indonesia menganjurkan agar ibu hamil mengonsumsi sedikitnya 90 pil zat besi selama kehamilan. ${ }^{7,22}$ Penerapan program pemberian suplementasi zat besi di Agats sudah sangat tepat untuk mencegah anemia pada kehamilan, namun efektivitas pemberiannya perlu dikaji lebih lanjut karena ternyata anemia pada ibu hamil masih banyak dijumpai.

Penelitian ini mempunyai keterbatasan antara lain ketidaklengkapan data yang diperoleh karena keterbatasan sumber daya manusia serta alat ukur yang tersedia. Data yang hanya mencakup berat badan, lingkar lengan atas, serta kadar hemoglobin kurang menggambarkan faktor risiko yang mungkin berperan dalam kejadian anemia pada ibu hamil di Agats. Tidak terdapat juga data mengenai distribusi maupun ketepatan konsumsi suplementasi zat besi. Sehingga, pada penelitian selanjutnya, beberapa variabel yang sebaiknya turut diperhitungkan adalah usia, BMI, status gravida, paritas, riwayat abortus, jarak antarkehamilan, jumlah anggota keluarga, tingkat pendidikan, pekerjaan, pendapatan tiap bulan, jumlah kunjungan ANC dan usia kehamilan saat memulai ANC, suplementasi asam folat, distribusi dan ketepatan maupun tingkat kepatuhan konsumsi suplementasi zat besi, konsumsi alkohol, status HIV, status infestasi parasit seperti malaria dan cacing tambang, ada atau tidaknya infeksi lain, ada atau tidaknya penyakit kronis, jenis konsumsi makanan sehari-hari di luar makanan yang sudah dibagikan, frekuensi makan per hari, serta kebiasaan pica. Luaran dari kelahiran seperti lahir preterm, berat badan lahir rendah, janin tumbuh lambat, atau janin meninggal di dalam kandungan juga perlu diperhitungkan.

Selain itu, referensi Asmat dalam Angka maupun laporan evaluasi Program 1000 HPK bulan Oktober - Desember 2017 yang digunakan pada penelitian ini kemungkinan kurang sahih. Pengambilan data atau pencatatan sipil terkendala oleh sumber daya manusia yang kurang serta kondisi geografis yang sulit. Asmat begitu besar dan terpisahkan oleh sungai yang sangat luas. Referensi ilmiah lain tentang Asmat juga masih sangat terbatas sehingga sulit ditemukan pembanding dalam penelitian ini. Diperlukan juga penelitian kuantitatif dan kualitatif untuk menemukan faktor risiko pasti anemia ibu hamil di Agats, Asmat, Papua, agar kebijakan yang dilakukan lebih tepat.

\section{Kesimpulan}

Prevalensi anemia pada ibu hamil peserta Program 1000 HPK di Agats, Asmat, Papua masih tinggi, jika dibandingkan dengan prevalensi nasional. Berdasarkan observasi yang dilakukan, kemungkinan faktor risiko anemia pada ibu hamil di Agats, Asmat mencakup letak geografis yang kurang menguntungkan, angka kejadian malaria yang cukup tinggi, rendahnya tingkat pendidikan 
masyarakat, kurangnya perhatian masyarakat terhadap kesehatan, keadaan sosioekonomi yang rendah, serta tingginya kurang gizi pada ibu hamil. Perlu penelitian lebih lanjut untuk mengevaluasi ragam faktor risiko serta hubungannya dengan kejadian anemia pada ibu hamil di Agats, Asmat, Papua.

\section{Ucapan terima kasih}

Penulis mengucapkan terima kasih kepada seluruh staf Pemerintah Daerah Kabupaten Asmat, Rumah Sakit Umum Daerah Agats, dan Puskesmas Agats yang telah menerima kami dengan baik, serta memfasilitasi pelaksanaan program KKN-PB UGM PA-001 sehingga dapat berjalan lancar. Terima kasih juga kami sampaikan kepada Direktorat Pengabdian Kepada Masyarakat (DPKM) UGM atas bantuan administratif dan dana pelaksanaan kegiatan pengabdian. Penulis juga berterima kasih kepada Fazlur Risyad Laochi sebagai koordinator unit KKNPB PA-001 UGM, Herdhina Dwi Jawanti, Jendi Alfian Alza, Arum Rarasati, Aurelia Maria Ozora Diomarizka, Nadia Adelin, Muhlifain Nauminingtyas, dan Dyan Puspitasari selaku anggota tim KKNPB PA-001 UGM yang telah membantu mulai dari perencanaan hingga pelaksanaan kegiatan pengabdian dan penelitian ini.

\section{Daftar Pustaka}

1. Kementerian Kesehatan Republik Indonesia. Penderita menurun, status KLB campak Asmat dicabut [Internet]. Agats: Kementerian Kesehatan Republik Indonesia; 2018 [updated 2018 Feb 5; cited 2018 Aug 2018]. Available from: http://www.depkes.go.id/article/ view/18020600001/penderita-menurunstatus-klb-campak-asmat-dicabut.html

2. Yuningsih R. Pendekatan kesehatan masyarakat pasca kejadian luar biasa (KLB) di Kabupaten Asmat Papua. Bidang Kesejahteraan Sosial Pusat Penelitian Badan Keahlian DPR RI. 2018;10(4).

3. Soma-Pillay $P$, Nelson-Piercy C, Tolppanen $\mathrm{H}$, Mebazaa A. Physiological changes in pregnancy. Cardiovasc J Afr. 2016;27(2):89-94.
4. Sifakis $S$, Pharmakides $G$. Anemia in pregnancy. Ann N Y Acad Sci. 2006;900(1):125-36.

5. Stephen G, Mgongo M, Hashim TH, Katanga J, Stray-pedersen B, Msuya SE. Anaemia in pregnancy: Prevalence, risk factors, and adverse perinatal outcomes in Northern Tanzania. Anemia. 2018;2018.

6. World Health Organization. The global prevalence of anaemia in 2011 [Internet]. Geneva: World Health Organization; 2011 [cited 2018 Aug 30]. Available from: http://apps.who.int/iris/ bitstream/10665/177094/1/9789241564960_ eng.pdf?ua=1

7. Badan Penelitian dan Pengembangan Kementerian Kesehatan Republik Indonesia. Riset kesehatan dasar 2013. Jakarta: Departemen Kesehatan Republik Indonesia; 2013. 384 p.

8. Black RE, Victora CG, Walker SP, Bhutta ZA, Christian $\mathrm{P}$, De Onis $\mathrm{M}$, et al. Maternal and child undernutrition and overweight in lowincome and middle-income countries. Lancet. 2013;382(9890):427-51.

9. Taner CE, Ekin A, Solmaz U, Gezer C, Çetin B, Kelesoglu $\mathrm{M}$, et al. Prevalence and risk factors of anemia among pregnant women attending a high-volume tertiary care center for delivery. J Turk Ger Gynecol Assoc. 2015;16(4):231-6.

10. Pemerintah Kabupaten Asmat - Papua Indonesia. Pemkab Asmat canangkan Gerakan 1000 Hari Pertama Kehidupan [Internet]. 2017 [cited 2018 Aug 30]. Available from: http:// www.asmatkab.go.id/article/pemkab-asmatcanangkan-gerakan-1000-hari-pertamakehidupan

11. Calkins LA. Blood transfusion in obstetrics and gynecology. RCOG Greentop Guidel. 2015;22(8):704-7.

13. Pemerintah Kabupaten Asmat. Geografi [Internet]. Asmat, Papua: Pemerintah Kabupaten Asmat; 2017 [cited 2018 Aug 30]. Available from: http://www.asmatkab.go.id/ page/geografi

14. Belarminus R. Curhat Mensos dan Menkes 
soal tantangan kondisi geografis Asmat [Internet]. Jakarta: Kompas.com; 2017 [updated 2018 Jan 29; cited 2018 Aug 30]. Available from: https://nasional.kompas.com/ $\mathrm{read} / 2018 / 01 / 29 / 20031241 /$ curhat-mensosdan-menkes-soal-tantangan-kondisi-geografisasmat

15. Cox JT, Phelan ST. Nutrition during pregnancy. Obstet Gynecol Clin North Am. 2008;35(3):36983.

16. Badan Pusat Statistik Kabupaten Asmat. Kabupaten Asmat dalam angka 2017. Asmat, Papua: Badan Pusat Statistik Kabupaten Asmat; 2017.

17. Puskesmas Agats. Laporan evaluasi Program 1000 HPK Oktober - Desember 2017. Agats, Asmat, Papua: Puskesmas Agats; 2017.

18. Melku M., Addis Z, Alem M, Enawgaw B. Prevalence and predictors of maternal anaemia during pregnancy in Gondar, Northwest Ethiopia: An institutional based cross-sectional study. Anemia. 2014;2014.

19. Tanzania Bureau of Statistics. Tanzania demographic and health survey 2016. Tanzania, Maryland: National Bureau of Statistics Dar es Salaam, Tanzania ICF Macro Calverton; 2016. $482 \mathrm{p}$.

20. Linggasari $D$. Realitas di balik indahnya ukiran: Potret keseharian Suku Asmat di Kecamatan Agats. Yogyakarta: Kunci Ilmu; 2002.

21. Al-Mehaisen L, Khader Y, Al-Kuran O, Abu Issa $\mathrm{F}$, Amarin Z. Maternal anemia in rural Jordan: Room for improvement. Anemia. 2011;2011.

22. Pemerintah Indonesia. Rancangan 5 September 2011: Rencana pengembangan tenaga kesehatan tahun 2011 - 2025. Jakarta: Pemerintah Indonesia; 2011.

23. World Health Organization. WHO Recommendation on antenatal care for positive pregnancy experience [Internet]. Geneva: World Health Organization; 2016 [cited 2018 Aug 30] 172 p. Available from: http://apps.who.int/iris/bitstream/hand le/10665/250796/9789241549912-eng. pdf?sequence $=1$
24. Tang AM, Dong $K$, Deitchler $M$, Chung $M$, Maalouf-Manasseh Z, Tumilowicz A, et al. Use of cutoffs for mid-upper arm circumference (MUAC) as an indicator or predictor of nutritional and health- related outcomes in adolescents and adults: A systematic review. Food Nutrition Technical Assistance. 2013;(November):1-37.

25. Ververs M-T, Antierens A, Sackl A, Staderini N, Captier V. Which anthropometric indicators identify a pregnant woman as acutely malnourished and predict adverse birth outcomes in the humanitarian context?. PLOS Curr. 2013;Jun(1).

26. Lubis Z, Fitria M. Chronic energy malnutrition and anemia in pregnant women in Medan. Proceedings of the 1st Public Health International Conference. 2016;1(PHICo 2016):337-40.

27. Haldar K, Mohandas N. Malaria, erythrocytic infection, and anemia. Hematology. 2010;1(574):87-93.

28. Dinas Kesehatan Provinsi Papua. Profil kesehatan Provinsi Papua tahun 2016. Jayapura, Papua: Dinas Kesehatan Provinsi Papua; 2017. 163 p.

29. Rahmati S, Delpishe A, Azami M, Hafezi Ahmadi MR, Sayehmiri K. Maternal anemia during pregnancy and infant low birth weight: A systematic review and meta-analysis. Int J Reprod Biomed (Yazd). 2017;15(3):125-34.

30. Kumar KJ, Asha N, Murthy DS, Sujatha M, Manjunath V. Maternal anemia in various trimesters and its effect on newborn weight and maturity: An observational study. Int J Prev Med. 2013;4(2):193-9. 